\title{
Competency test for selecting majors to produce competitive vocational graduates in industry
}

\author{
Agus Aan Jiwa Permana ${ }^{1, *}$, Ni Ketut Kertiasih $^{1}$, and Kadek Suranata ${ }^{2}$ \\ ${ }^{1}$ Department of Information Management, Universitas Pendidikan Ganesha, Indonesia \\ ${ }^{2}$ Department of Counseling Guidance, Universitas Pendidikan Ganesha, Indonesia
}

\begin{abstract}
President of Indonesia, Jokowi reoriented vocational school graduate toward demand driven graduates that is graduates who have certificate and skill required by industry. The initial stage of the new student on vocational school is choosing a major. At first step, students often confuse in choosing the majors they want. The mistake of choosing a department will be a set beck to the motivation of learning and skill, later will impade students future career. Thus competence test is needed to helping them in choosing the majors according to their competence. The solution to this problem is to conduct online competency tests for new students. The Results of research with 60 responden, $78 \%$ corresponds stated that the majors they were in match with their interests. Then the remaining $22 \%$ did not match. But the result of the competency assessment of students in match with the majors of is $40 \%$ and $60 \%$ of students need counseling for selection majors.
\end{abstract}

\section{Introduction}

The public opinion in Indonesia about education is now shipting. Public in Indonesia is more interested in sending their children to Vocational High School (VHS) than Senior High School (SHS) after finishing study at junior high. Studies shown that parents want their children to be ready for work after finishing study if they can not afford for higher education [1]. Consequently government has set a policy to cover the shortage by increasing the ratio of VHS : SHS To 70:30. The idea behind the increasing ration in favor of VHS is that it is expected to produce skillfull and intellectual class among the work force [2]. Many other countries are now follow the policy of increasing the ration. Among them is Malaysia. It is clearly stated by [4] who emphesized that fruitfull shifting toward Vocational High School is a major transformation in vocational education in Malaysia. President Jokowi stressed the importance of reorientation of education and vocational training in the direction of demand driven by the certification in accordance with the demands of industry. He also mentioned that the Indonesian population is dominated by young people by $60 \%$. With such a large percentage, Indonesia should be able to increase

*Corresponding author: agus.aan@undiksha.ac.id 
its workforce without having to import labor from abroad. One of the leading sectors of VHS is the computer majors that entered in 15 majors VHS promising the future in the field of multimedia [5].

In a National Conference of Vocational and Technological (Semnasvoktek) organized by the Faculty of Engineering and Vocational, Undiksha Dr. I Ketut Suarnaya, M.Pd as a keynote speakers mentioned that the slogan VHS is Working, Continuing, and Selfemployed abriviated as WCE. The slogan indicates that the vocational school graduates has aplicable competence. However, practically the effort to reduce unemploiment by increasing the ration is not good. The same data was also recorded by the Central Bureau of Statistics which stated that viewed from the educational background, the largest proportion of unemployed are those graduates of VHS $9.84 \%$. This figure is higher than the unemployed high school graduates $6.95 \%$, junior $5.76 \%$, and primary $3.44 \%$ [4] Vocational students need to be equipped with risk analysis preventing risk Many feel that they themselves are primarily responsible for performing their duties safely while in practice [6].

It is commonly found that students in choosing education program are baseless. They often choose education program randomly whitout consulting their potention such as the basic common abilities (intelligence), talents, interests and physical and socio-cultural conditions and their career interests. One of the efforts that can be done is to prepare the assessment tool to help students understand the potential and the condition of self including the general basic ability (intelligence), talents, interests and physical condition as well as social culture and career interests of students [7]. After the selection process, it should also be noted that the curriculum is based on a competency approach to train vocational students [8]. The success of those affected by many factors which allow cognitive variables, interest and personality should be evaluated together in predicting success [9].

[10] said that an inventory personal survey tests can be used to screen for potential new students. The test is aimed to place students according to their interests with the right areas of expertise which can increase their motivation. The success of a vocational education according to Erlin Leigh Parker (2008, in [10]) is influanced by many factors, one of them is the recruitment of the students. Good recruitment process and adequate facilities will automatically produce competent graduates. In the near future, the system will be online-based, making it easier for participants who are away from school and has limited time can take the test. it is supported by [8] who stated that technology can be used for steering student in choosing a career in accordance with personality and competence. With a good selection process, and adequate facilities will produce graduates who are competent and ready to compete in the world of work. After the selection process, it should also be noted that the curriculum is based on a competency approach to train vocational students [11]. Meanwhile, the limited number of conselor and inbalance in ratio between the conselor and students is the main constraint. It makes face-to-face counseling service less effective. In addition, there is a tendency of current trend that counselee feel uncomfertable if the conseling is conducted face to face [12]. Based on the above explanation, it is necessary to develop an assessment instrument that can be accessed online through the internet network to assist the selection that can give the students recommendations in choosing the majors, especially in the vocational school.

\section{Literature Review}

\subsection{Vocational Education}

Vocational education embraces an open system (multientryexit system) and multimakna (oriented to culture, empowerment, character formation, and personality, and life skill) [13]. Even overseas The Italian Government has been in the context of implementing its Digital Agenda overhauling the education system in the country where all 
children have the right to attend education and training for at least 12 years, applicable for students aged 15 years or older who can be accepted for internship in the company because it is already Signed an agreement with MIUR (Department of Labor) [14]. Based on the vocational exposure above, in the vocational education system there is a difference with the education system in high school because students are directed to become a workforce ready to compete at the industry level. Industry is in dire need of manpower who has the skills to work in certain fields eg in tourism, computers, fisheries, maritime, shipping, agriculture, plantation, pharmacy, catering, fashion, automotive, hotel, accounting, office administration, banking, travel, And marketing. So that the role of vocational schools and colleges and colleges should cooperate with the government and industry to produce demand driven labor such as the expectations of Mr. President Jokowi. [15] wrote an article that says that there are three features in vocational education, among others : 1 . More Practical: If you feel attending college classes are boring, do not like doing assignments and assessed by exam, you may consider vocational education. Vocational education actually trains practical skills, so of course more practice than theory. 2. Many institutional options: Unlike undergraduate degree education and so on, vocational education is offered by more institutions, whether universities, colleges, polytechnics, training centers or other institutions that specialize in vocational education programs. 3 . Various programming options: Vocational education is suitable for those who are clear and confident about what they want to pursue as future careers. Lots of fields are available ranging from tourism and hospitality, retail management, software development, interior design, automotive engineering, hair styling to culinary.

\subsection{Test Inventory Personal Survey}

Before humans recognize measurement tools that are now known as personality inventory, attempts to get personality traits have existed in such a way as to see the hand line, face, date/day of birth, and other endeavors [1]. Personality measurement is important in the knowledge of careers since 75 years ago (1918s), although much centered on abnormal personality, this has also been done in normal personality, especially to help individuals make selection in the choice of job As well as positions [1, 16]. Characterizes people with similarities in six personality types: realistic, investigative, artistic, social, enterprising, and conventional (RIASEC) [17]. A person's suitability and environment can lead a person to predict and understand knowledge about personality types and environmental models. This will be highly beneficial for job options, vocational stability and achievement, choice of education and achievement, individual competence, social behavior, and to affect one's sensitivity. Self Direct Search Inventory (SDS) inspired from Holland's personality and career theory (1975). SDS is a type of developed by Holland through the adaptation and refinement of Vocational Preference Inventory (VPI) made in 1958, has been revised three times and the linventory ast of 2001, has been used and adapted over 20 nations in the world with versions over 15 Language, and has been proven through various studies in measuring personality types and providing career predictions suitable for students and students as well as for those already in the workforce $[1,16]$. The developed Personal Inventory Personal Survey (TIPES) has four indicators: (1) interest and involvement in an activity, (2) self-perception of ability to perform a field/skill, (3) interest and interest in a particular occupation or occupation, (4) self-assessment to be able to work on certain areas of expertise.

\subsection{Web Based}

Terminologically website is a collection of web pages, usually summarized in a domain or subdomain, located within the World Wide Web (WWW) on the Internet. A web page is a document written in HTML (Hyper Text Markup Language) format, which is 
almost always accessible via HTTP, a protocol that conveys information from a website server to be displayed to users via a web browser. All publications from these websites can form a huge information network. The pages of the website will be accessible through a URL called Homepage. This URL sets the pages of a site to be a hierarchy, though, the hyperlinks on the page govern the readers and tell them the overall susceptibility and how this information flows through.

\section{Method}

In the early stages of the study, the subject were students of state VHS and Private VHS in Buleleng. Research in phase I (year 2017) focused on identification of personality type model that corresponds to vocational areas (majors) in VHS based on personal inventory survey test and its correlation with student achievement involving sample of student of VHS in Buleleng Regency determined by cluster technique sample area The validity test involves: (1) counselors expert; (2) educational/ICT media specialists, and (3) Counseling teacher practitioners (school counselors) as assessors of the design of online test systems. Small-scale test of the implementation of a online test system will be done with the subject of Vocational High School students in SMKN 3 Singaraja for engineering majors (Engineering), SMKN 1 Sukasada for industrial majors(Industry), State SMKN 1 Seririt for tourism majors (Tourim).

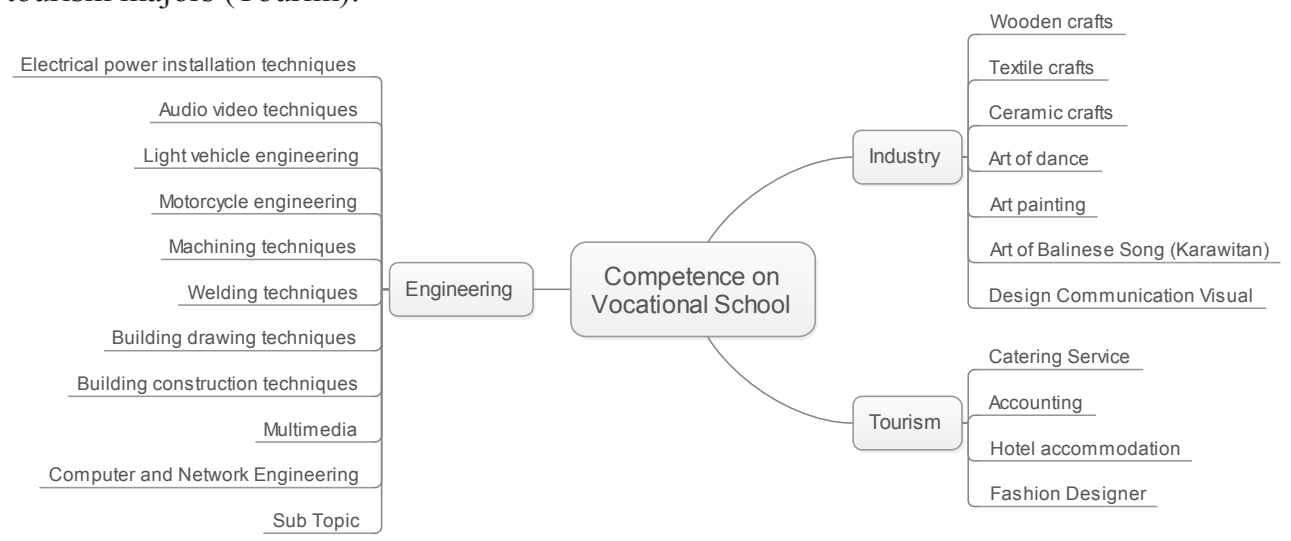

Fig. 1. Mapping majors at vocational schools

$$
C=\{3(c 1)+2(c 2)+1(c 3)\}
$$

Information about equation 1 :

$$
\begin{array}{ll}
\mathrm{C} & =\text { Conggressive Scores or Conformity Scores } \\
\mathrm{C} 1 & =\text { first digit match score } \\
\mathrm{C} 2 & =\text { second digit match score } \\
\mathrm{C} 3 & =\text { third digit match score }
\end{array}
$$

The process of collecting data is done by giving questionnaires to students which contains four parts. Section A from the numbers 1 (one) to 66 (sixty six) were statements related to daily activities. With a response time of 15 minutes. Section B contains items of statements from number 67 (sixty seven) to 132 (one hundred and thirty two) were statements related to areas of expertise or competence. With a response time of 15 minutes. Section $\mathrm{C}$ contains 
Item statements from number 133 (one hundred and thirty three) to 210 (two hundred and ten) were relatated to various types of work. Those types of works were devided into two parts, one part is the kinds of work the students love and the other part is the kind of work students do not want. With an answer time of 20 minutes. Section D contains The statement items from 211 (two hundred and one) to 216 (two hundred and sixteen) corresponded to different types of talents and areas of expertise. With answering time for 5 minutes.

Table 1. Relation of Majors \& Interest Base on School Type

\begin{tabular}{|lccc|}
\hline \multicolumn{1}{|c|}{ School Type } & \multicolumn{2}{c|}{ Relation of Majors \& Interest } & total \\
& Correct & Incorect & Responden \\
Engineering & 27 & 3 & 30 \\
Industry & 10 & 10 & 20 \\
Hotel dan Tourism & 10 & 0 & 10 \\
Totally : & 47 & 13 & 60 \\
Percentage : & $78 \%$ & $22 \%$ & $100 \%$ \\
\hline
\end{tabular}

\section{Result and Discussion}

After the test is done then the results will be displayed directly, whether the user's competence in accordance with the profile of the majors are planned to be selected. Based on the results of research from three schools with different skills obtained from 60 responden the result is that $78 \%$ corresponds stated that the majors they were in match with student interests. Then, the remaining $22 \%$ did not match. There was a difference to the degree of mismatch between the departments and the students' interest, $50 \%$ in industrial schools and only $10 \%$ occurred in technical schools in Table 1 . The result of competency indicated that, $60 \%$ of students need counseling and more specifically for primary, secondary, tertiary test results can be seen as Figure 2 .

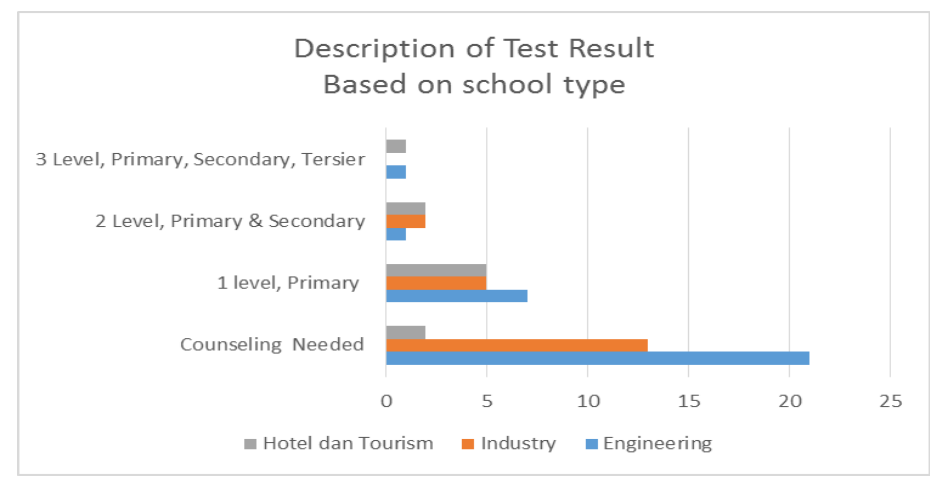

Fig. 2 Description of Result Based on School Type

\section{Conclusion}

The conclusion of this research is to give the right recommendations to the students in choosing the department. The degree of conformity of majors with student interest is good. But the result of the competency assessment of students in accordance with the department 
is $40 \%$. With the system developed, students are more confident in choosing the majors in accordance with their interests and desired skills. The right placement will improve students' learning motivation in the classroom. Thus after students finished their education at VHS, they will have a successful career in the industry that is Demand driven graduates and also produce graduates who are equipped with entrepreneurial spirit to create new jobs oportunity to reduce unemployment in Indonesia.

\section{Acknowledgment}

Thanks to teachers and schools that provide valuable data such as SMKN 3 Singaraja, SMKN 1 Sukasada, and SMKN 1 Seririt. The greatest thanks is given to Universitas Pendidikan Ganesha that provided funding for the early stages of this research through DIPA 2017 funding entitled "Online Assessment Personal Survey (TIPES) as a Selection Recommendations Major On Vocations School".

\section{References}

1. Suranata, K., 2009, Relationship Between Conformity of Personality Type and Environmental Model with Maturity of Career Choice Choice (Study on Grade XII Students at State VHS 1 Padang), Thesis, Guidance and Counseling Study Program, Graduate Program, State University of Padang, Padang. (in Indonesian)

2. Lewis, H. W. and Jorgensen, B. (2015) 'Sweat and Brains : A Look into Intellectual and Vocational Trends , and their Importance'.

3. Rahman, A., Hanafi, M. and Ibrahim, M. (2014) 'Assessment Practices for Competency Based Education and Training in Vocational College, Malaysia', Procedia - Social and Behavioral Sciences. Elsevier B.V., 112(Iceepsy 2013), pp. 10701076. doi: 10.1016/j.sbspro.2014.01.1271.

4. Public Relations, the Majority of Unemployed Vocational Graduates, President Jokowi Ask Vocational Education System Removed, http://setkab.go.id/category/berita/, (accessed: October 28, 2016) (in Indonesian)

5. Supriani, Nanda Fitri, Here are 15 Promising Future Vocational Schools in the Future, http://Papasemar.Com/Author/NandaFitri-Supriani/, (accessed: October 28, 2016) (in Indonesian)

6. Andersson, I., Gunnarsson, K., Rosèn, G. and Åberg, M. M. (2014) 'Knowledge and Experiences of Risks among Pupils in Vocational Education', Safety and Health at Work. Elsevier Ltd, 5(3), pp. 140-146. doi: 10.1016/j.shaw.2014.06.002.

7. Kemendikbud. Specialization Guidelines for Learners. Agency for Human Resource Development Education and Culture and Quality Assurance of Education: Ministry of Education and Culture, 2013 (in Indonesian)

8. Yang, H. H. (2016) 'Have Learned about Students in Educational Technology Major'. doi: 10.1109/EITT.2016.53.

9. Volodina, A., Nagy, G. and Köller, O. (2015) 'Success in the fi rst phase of the vocational career: The role of cognitive and scholastic abilities, personality factors, and vocational interests ¿', Journal of Vocational Behavior. Elsevier Inc., 91, pp. 11-22. doi: 10.1016/j.jvb.2015.08.009.

10. Asmara, Andik dan Haryanto. Development of Interest And Talent Test Using Artificial Neural Network Method (ANN) to Predict Potential Student in Robotics Field, Journal of Vocational Education, Vol 5, Number 3, Page. 273-286, November 2015 (in Indonesian)

11. Kateryna, R. (2015) 'Competency-build approach to the unitizing of vocational schools', (September), pp. 471-476.

12. Hidayah, N \& Ramli,M. Development of an online Behavioral Cognitive Counseling Model based online to manage Junior high school students SRL in Malang Raya. Research Report. Malang: Research Institute of UM (2013) (in Indonesian)

13. Universitas Brawijaya, About Vocational, http://vokasi.ub.ac.id/tentang-vokasi/, (Accessed : 28 Oktober 2016) (in Indonesian)

14. Nazzaro, Antonio, The Italian national plan for digital school in the framework of the Digital Agenda for Europe, http://s3.amazonaws.com/academia.edu.documents/33373326/nazzaro_dubai_invio.pdf?awsaccesskeyid=akiaj56tqjrtwsmtnp ea\&expires $=1477648954 \&$ signature $=l \mathrm{~cm} v z \mathrm{pvxw} \% 2 \mathrm{~b} 6 \mathrm{khvxijbg} 67 \mathrm{mrnlhw} \% 3 \mathrm{~d} \&$ response-content disposition=attachment\%3b\%20filename \%3dthe_italian_national_plan_for_digital_sc.pdf , 2016, (diakses: 28 Oktober 2016)

15. HC Indonesia, 3 Vocational Education http://www.hotcourses.co.id/studyabroadinfo/subjectinfo/3keistimewapendidikankejuruanvokasi/, 2014, Accessed (October $28,2016)$ (in Indonesian)

16. Nauta, M.M. The Development, Evolution, and Status of Holland's Theory of Vocational Personalities: Reflections and Future Directions for Counseling Psychology. Journal of Counseling Psychology, 57 (11),pp. 11-22. DOI: 10.1037/a0018213. 2010

17. Holland, J., Making Uccupation Choise, Prentice-Hall, New Jersey, 1985

18. Miller, Springer, Tobacyk \& Wells. 2004. Congruency Between SDS Personality Type and Environmental Model. College Student Journal. (online). v.8, n.6073197, pg.2. (http://findarticles.com/p/articles/mi_mOFCR/is_1_38/ai_n6073197/pg_2), Diakses 24 Juli 2008.

19. Alfindasari, Dessy. Steps to Conduct Research and Development (R \& $\mathrm{D}$ ), http: //www.eurekapendidikan.com/2014/12/karakteristikrresearchanddevelopment.html, 2014, Accessed (October 28, 2016) (in Indonesian) 